\title{
Dephytinisation of rice bran and manufacturing a new food ingredient
}

\author{
Wea-Shang Fuh and Been-Huang Chiang* \\ Graduate Institute of Food Science and Technology, National Taiwan University, Taipei, Taiwan
}

\begin{abstract}
Rice bran was extruded at $130^{\circ} \mathrm{C}$ and a screw speed of $140 \mathrm{rpm}$ for $20 \mathrm{~s}$ to inactivate lipase and prevent lipid oxidation. Although the extrusion process induced further complex formation between phytic acid and protein as well as between phytic acid and starch, nearly $94 \%$ of phytic acid in the extruded rice bran could still be removed by solid/liquid extraction conducted at $25^{\circ} \mathrm{C}$ for $30 \mathrm{~min}$ using hydrochloric acid at pH 2 as solvent and a solvent/rice bran ratio of 15 . After the extract had been neutralised and phytic acid removed, it was added back to the rice bran solid to replenish the nutritional and functional components of the solid. The mixture was then dried in a drum dryer to yield a powdered product. The dephytinised rice bran product contained most of the protein, fat, dietary fibre and $B$ vitamins and more than $50 \%$ of the oryzanol originally present in the raw rice bran.

(C) 2001 Society of Chemical Industry
\end{abstract}

Keywords: rice bran; extrusion; phytic acid; nutrition

\section{INTRODUCTION}

During milling processes, approximately $20 \%$ of rough rice is milled off as shell, and then another $10 \%$ as rice bran to yield milled rice. Rice bran, containing 34$62 \%$ starch, $15-22 \%$ oil, $11-15 \%$ protein, $24-29 \%$ dietary fibre and $6.6-9.9 \%$ minerals, ${ }^{1}$ is a potential source of nutritious food ingredient. The protein in rice bran has a PER value of 1.99-2.38, which is close to that of casein. ${ }^{2,3}$ Rice bran oil consists of $77-82 \%$ unsaturated fatty acids. Its constituents are similar to those of peanut oil and are relatively stable. ${ }^{1}$ Crude rice oil contains $c a 4.2 \%$ unsaponifiable lipids, higher than other fats. These lipids are able to increase the excretion of bile acid and neutral steroids and to decrease the quantity of cholesterol both in blood serum and in the liver. ${ }^{4-7}$ Rice bran oil also contains vitamin $\mathrm{E}^{8,9}$ and oryzanol, ${ }^{10}$ both potent antioxidants. In addition to its antioxidative activity, oryzanol can decrease plasma cholesterol, ${ }^{11}$ facilitate blood circulation and stimulate hormone secretion. ${ }^{10}$ Rice bran is a good source of dietary fibre and is as effective as wheat bran in acting as a bulking agent and decreasing faecal transit time. Aoe et al ${ }^{12}$ conducted experiments on rats and found a reduction of cholesterol in serum when dispensed with an alkaline extract of the water-soluble fibres of rice bran. Ito et $a l^{13}$ demonstrated an inhibition of tumour growth by non-starch polysaccharides extracted from rice bran with hot water.

As in other cereals, phytate is also present in rice bran. At indigenous $\mathrm{pH}$, phytic acid is negatively charged and therefore reacts easily with positively charged substances. Consequently, phytic acid is often found in food as water-insoluble complexes, asso- ciated with metal cations, protein and starch, and considered a negative factor affecting the bioavailability of many essential elements in foods. ${ }^{14,15}$ Therefore removing phytate from rice bran before human consumption is essential.

Removal of phytic acid from legumes and cereals can be done by extraction with water or acidic solvents. ${ }^{16-18}$ Dephytinisation can also be achieved by hydrolysis of the phytate by endogenous phytase $^{16,19-22}$ or by application of microbial enzymes. ${ }^{16,23}$ However, little information is available concerning the effect of dephytinisation on the nutritional composition of the substances being treated.

Most rice bran is currently used for livestock feed or is discarded, and only a small proportion of it is used for oil extraction. However, rice bran is a source of many nutrients and health-promoting elements. It would be highly desirable to convert it to a high-value food ingredient. This study was conducted to develop a proper procedure for manufacturing a nutritious and health-promoting food ingredient from rice bran. The process includes rice bran stabilisation, phytic acid extraction and product formation.

\section{MATERIALS AND METHODS Materials}

Rice bran of 'Perng-Lai' variety, supplied by KuoGuang Co (Taipei, Taiwan), was packed in polyethylene bags and stored at $-20^{\circ} \mathrm{C}$ before use. Sulphuric acid, hydrochloric acid and formic acid were obtained from Riedel-de Haen Co (Seelze,

\footnotetext{
* Correspondence to: Been-Huang Chiang, 59, Lane 144, Keelung Road, Section 4, Taipei, Taiwan

E-mail: bhchiang@ccms.ntu.edu.tw

(Received 26 February 2001; revised version received 16 July 2001; accepted 10 August 2001)
} 
Germany). Iso-octane and methanol were purchased from Mallinckrodt Baker, Inc (Paris, Kentucky, USA). Ethyl acetate was obtained from Romil Chem Ltd (Leics, UK). Tetrabutylammonium hydroxide, sodium hydroxide and sodium acetate were purchased from Merck Co (Darmstadt, Germany). Hexane was purchased from Alps Chemical (Taipei, Taiwan). LAscorbic acid, cellulase (EC 3.2.1.4), $\alpha$-amylase (EC 3.2.1.1), protease (EC 3.4.24.4), papain (EC 3.4.22.2), inositol hexaphosphate, vitamin $B_{1}$, vitamin $\mathrm{B}_{2}$ and niacin (vitamin $\mathrm{B}_{3}$ ) were purchased from Sigma Chemical Co (St Louis, MO, USA). r-Oryzanol was obtained from Wako Pure Chem Co Ltd (Osaka, Japan).

\section{Extrusion process}

A co-rotating twin-screw extruder (model BC-45; Clextral Co, Firminy Cedex, France) was used for processing the raw rice bran. The extruder screw shaft was $100 \mathrm{~cm}$ in length. Twelve screw elements, including four $50 \times 15$ (length $(\mathrm{mm}) \times$ pitch $(\mathrm{mm}))$, two $50 \times 25$, one $100 \times 25$, two $100 \times 35$, two $100 \times 50$ and one $200 \times 50$, were installed. The die was composed of a single circular opening $1.1 \mathrm{~cm}$ in diameter. The screw was housed in a barrel equipped with an induction heater and a jacket with a circulating cooling water system to control the barrel temperature. Extrusions were carried out at screw speeds ranging from 9 to $250 \mathrm{rpm}$, barrel temperatures from 120 to $140^{\circ} \mathrm{C}$ and feed rates from 1.04 to $3.54 \mathrm{~kg} \mathrm{~min}^{-1}$. Under these experimental conditions the residence time of the rice bran in the extruder ranged from 12 to $300 \mathrm{~s}$.

\section{Extraction of phytic acid}

Phytic acid in the rice bran was extracted with hydrochloric acid solution. The $\mathrm{pH}$ of the solvent ranged from 1 to 6 , the rice bran/solvent ratio from 1:5 to $1: 25$, the extraction temperature from 25 to $55^{\circ} \mathrm{C}$ and the extraction time from 1 to $5 \mathrm{~h}$. Both the extractability of phytic acid and the purity of the phytic acid in the extract were investigated. The extractability (\%) of phytic acid was calculated by dividing the amount of phytic acid in the extract by the amount in the rice bran. The purity of the phytic acid in the extract was the ratio of the phytic acid concentration to the total solid concentration of the extract.

Extraction of phytic acid was also conducted after enzyme treatment to investigate the possibility of complex formation between phytic acid and other components in the rice bran due to extrusion. Rice bran was extruded at $130^{\circ} \mathrm{C}$ for $20 \mathrm{~s}$. Samples of the extruded rice bran $(1 \mathrm{~g}$ each) were placed in $125 \mathrm{ml}$ flasks with $15 \mathrm{ml}$ of acetate buffers of various $\mathrm{pH}$ values $(\mathrm{pH} 5$ for cellulase, $\mathrm{pH} 7.5$ for protease, $\mathrm{pH} 6.9$ for $\alpha$-amylase) and $150 \mathrm{mg}$ of the enzyme used. The mixtures were allowed to react at the optimal temperatures of the enzymes $\left(37^{\circ} \mathrm{C}\right.$ for cellulase and protease, $25^{\circ} \mathrm{C}$ for $\alpha$-amylase) for $2 \mathrm{~h}$ before being extracted with hydrochloric acid ( $\mathrm{pH} 2)$ at $25^{\circ} \mathrm{C}$ for $30 \mathrm{~min}$.

\section{Manufacture of rice bran product}

After extraction the required amount of $3 \mathrm{M} \mathrm{NaOH}$ solution was added to the extract to precipitate the phytic acid. The solution was then filtered to remove the precipitate. The filtrate, which contained the soluble portion of rice bran, was added back to the dephytinised rice bran solid to replenish the nutrients and functional components. The solid/liquid mixture was dehydrated in a drum dryer (Luh-Hae Mechanical Co, Taipei, Taiwan). The gap between the two drums of the dryer was set at $0.5 \mathrm{~cm}$. The rotation speed of the drum was $52 \mathrm{scycle}^{-1}$ and the surface temperature of the drum was $125 \pm 5^{\circ} \mathrm{C}$. Flakes produced from drum drying were ground with a cutter/grinder to obtain a powdered product containing $10 \%$ moisture.

\section{Analytical methods}

Moisture content of the sample was determined by drying at $105^{\circ} \mathrm{C}$ to constant weight. ${ }^{24}$ Crude protein was measured by the improved Kjeldahl method, and crude fat by the Soxhlet method. ${ }^{24}$ For ash content determination a $3-5 \mathrm{~g}$ sample was placed in a shallow and relatively broad ashing dish (which had previously been ignited, cooled in a desiccator and weighed soon after reaching room temperature), ignited in furnace at ca $550^{\circ} \mathrm{C}$ until light grey ash resulted, or to constant weight ( $c$ a $8 \mathrm{~h}$ ), then cooled in a desiccator and weighed soon after reaching room temperature. ${ }^{24}$ The soluble and insoluble dietary fibre was determined following the method of Prosky et al. ${ }^{25}$ After the sample had been treated with $\alpha$-amylase, protease and amyloglucosidase, the mixture was filtered. The insoluble dietary fibre (IDF) residue was dried and weighed, while the filtrate was transferred to a $600 \mathrm{ml}$ beaker and mixed with four volumes of $95 \%$ ethanol. The mixture was filtered and the residue (soluble fibre) was dried and weighed (SDF). After corrections for ash and protein had been made, values of SDF and IDF were obtained.

Acid value was analysed by first mixing $5 \mathrm{~g}$ of sample with $50 \mathrm{ml}$ of ether solution in a $125 \mathrm{ml}$ flask. After homogenisation of the mixture and addition of $0.3 \mathrm{ml}$ of phenolphthalein as indicator, the solution was titrated with $0.05 \mathrm{M} \mathrm{KOH}$ until a faint pink colour appeared and persisted for at least $30 \mathrm{~s}$. Acid value $=\mathrm{ml}$ $\mathrm{KOH}$ solution $\times$ molarity of $\mathrm{KOH} \times 2 \times 56.1 \mathrm{~g}^{-1}$ sample. ${ }^{24}$ For phytic acid determination, $1 \mathrm{~g}$ of sample was extracted with $20 \mathrm{ml}$ of $0.5 \mathrm{M} \mathrm{HCl}$ for $30 \mathrm{~min}$. The phytic acid was separated from the crude extract in an anion exchanger (model AGI-X8, 200-300 mesh; BioRad Co, Hercules, CA, USA) and analysed by highperformance liquid chromatography (HPLC) using $0.05 \mathrm{M}$ formic acid/methanol (49:50) solution and $1.5 \%$ tetrabutylammonium hydroxide as the mobile phase. ${ }^{26}$ The inositol phosphates were separated using a LiChrospher $100 \mathrm{RP}-18$ column $(4 \mathrm{~mm} \times 250 \mathrm{~mm}$, $5 \mu \mathrm{m}$; Merck Co) and detected by a refractive index detector (model RI-930; Jasco, Japan). Inositol hexaphosphate (Sigma Chemical Co) was used as an 
external standard to quantify the amount of phytate in the sample.

The analysis for oryzanol in rice bran was based on that reported by Shin et al. ${ }^{27}$ A $0.5 \mathrm{~g}$ sample was mixed with $5 \mathrm{ml}$ of ethanol and $0.1 \mathrm{~g}$ of ascorbic acid and heated in an $80^{\circ} \mathrm{C}$ water bath for $10 \mathrm{~min}$. The mixture was then saponified by adding $0.15 \mathrm{ml}$ of $80 \% \mathrm{KOH}$ and heated at $80^{\circ} \mathrm{C}$ for $15 \mathrm{~min}$. The reaction was terminated by cooling in an ice bath, after which $3 \mathrm{ml}$ of water and $5 \mathrm{ml}$ of hexane were added. After centrifugation $(120 \times g$ for $1 \mathrm{~min})$ the upper layer was transferred to a $125 \mathrm{ml}$ separatory funnel. Extraction of the sample with $5 \mathrm{ml}$ of hexane was repeated twice. The pooled hexane extracts were washed three times with $5 \mathrm{ml}$ of water, dehydrated by anhydrous $\mathrm{Na}_{2} \mathrm{SO}_{4}$ and then blown by a current of high-purity nitrogen. The crude oil sample was diluted with $1 \mathrm{ml}$ of iso-octane and analysed by HPLC using iso-octane/ ethyl acetate/acetic acid/2,2-dimethoxypropane (98.15:0.9:0.85:0.1) as the mobile phase. The separation was performed on a Supelcosil ${ }^{\text {(ix }}$ LC-Si column $(4.6 \mathrm{~mm} \times 150 \mathrm{~mm}, 5 \mu \mathrm{m}$; Supelco, Bellefonte, PA, USA) and detected by a UV detector (model UV-970; Jasco) at a wavelength of $295 \mathrm{~nm}$. The mobile phase

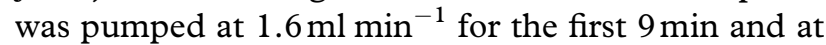
$2.4 \mathrm{ml} \mathrm{min}^{-1}$ for the next $7 \mathrm{~min}$. An external standard prepared by dissolving r-oryzanol (Wako Pure Chem Co Ltd) in the mobile phase was used for the analysis.

Vitamins $B_{1}, B_{2}$ and $B_{3}$ (niacin) in the sample were determined based on the method reported by Toma and Tabekhia. ${ }^{28}$ A $5 \mathrm{~g}$ sample was mixed with $50 \mathrm{ml}$ of $0.05 \mathrm{M}$ sulphuric acid and heated at $121^{\circ} \mathrm{C}$ for $30 \mathrm{~min}$ in a retort. After cooling, the $\mathrm{pH}$ of the sample was adjusted to 4.5 using $2 \mathrm{M}$ sodium acetate. The starch and protein in the sample were then hydrolysed by adding $0.5 \%(\mathrm{w} / \mathrm{v}) \alpha$-amylase and $1 \%(\mathrm{w} / \mathrm{v})$ papain and incubating at $35^{\circ} \mathrm{C}$ overnight. The sample was diluted with deionised water, filtered through a $0.45 \mu \mathrm{m}$ filter (Whatman International Ltd, Maidstone, UK) and analysed by HPLC. The HPLC system was equipped with a LiChrospher $100 \mathrm{RP}-18$ column ( $4 \mathrm{~mm} \times$ $250 \mathrm{~mm}, 5 \mu \mathrm{m}$; Merck Co) and a UV detector (model UV-970; JASCO) set at a wavelength of $254 \mathrm{~nm}$. The mobile phase, pumped at a rate of $0.8 \mathrm{ml} \mathrm{min}^{-1}$, was composed of $1000 \mathrm{ml}$ of methanol/water/glacial acetic acid (39:60:1) together with $20 \mathrm{ml}$ each of PIC-B5 and PIC-B7 (Waters Co, Milford, MA, USA).

Minerals contents were analysed by inductively coupled plasma atomic emission spectrometry (ICPAES) (model ICAP 9000; Jarrell-Ash, USA). Samples of $0.2 \mathrm{~g}$ were mixed with $1 \mathrm{ml}$ of concentrated nitric acid $(65 \%)$ and digested at $180^{\circ} \mathrm{C}$ for $4 \mathrm{~h}$ in a closed container. The digested samples were then diluted with $250 \mathrm{ml}$ of deionised water and analysed by ICP-AES.

\section{Statistical analysis}

One-way analysis of variance (ANOVA) was conducted using the SAS package (SAS Institute Inc, Cary, NC, USA). Duncan's multiple-range test was used to determine significant differences between treatments.

\section{RESULTS AND DISCUSSION Stabilisation process}

Rice bran, containing up to $22 \%$ oil, is a very unstable material, because its oil can increase in free fatty acids from the $2-3 \%$ typical in freshly milled rice bran to as much as $10 \%$ within a single day. ${ }^{29}$ Extrusion is a common method used for stabilising rice bran. ${ }^{29-31}$ The process inactivates the lipase in rice bran, preventing lipids from hydrolysis during storage. ${ }^{32}$ Extrusion can also convert the powdered rice bran to a pellet-type product which disperses more easily in the solvent during extraction, thus facilitating the phytic acid removal process. However, phytic acid may form complexes with starch or proteins in the rice bran. ${ }^{33}$ Extrusion cooking may enhance this complex formation and thus hinder the subsequent phytic acid removal process. Therefore the effects of extrusion on both the storage stability and phytic acid extractability of rice bran were investigated in this study.

It was found that rice bran extruded at a temperature above $130^{\circ} \mathrm{C}$ for more than $20 \mathrm{~s}$ could be stored at room temperature $\left(25^{\circ} \mathrm{C}\right)$ for at least 20 days without showing significant changes in acid value (Fig 1), suggesting that this process condition could inactive lipase and prevent fat from hydrolysis. The high temperature and pressure of the extrusion process also led to a sudden pressure drop when the rice bran emerged from the die, causing rapid vaporisation of water. Consequently, the water content of the rice bran after extrusion was reduced from 11 to $7 \%$. The dehydration effect of extrusion also improved the storage stability of rice bran.

Phytic acid in the extruded rice bran was extracted with hydrochloric acid solution at $\mathrm{pH} 2$ at room

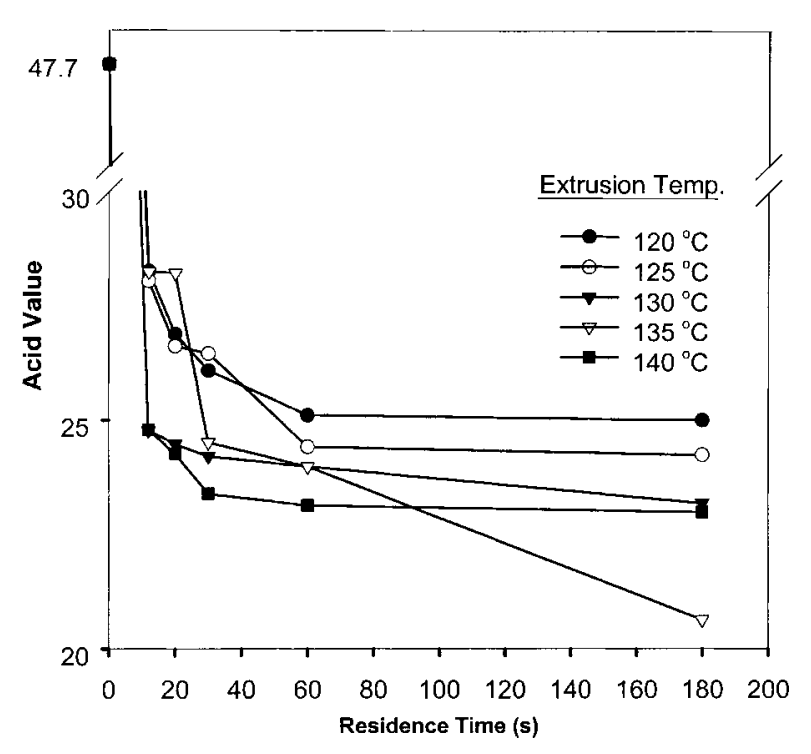

Figure 1. Effect of extrusion temperature and time on the acid value of rice bran after storage at $25^{\circ} \mathrm{C}$ for 20 days. 
temperature. The extractability of phytic acid was evidently affected by the extrusion (Table 1 ). The extractability of phytic acid from raw rice bran was $77.6 \%$. The extrusion process reduced the extractability to a value ranging from 53.3 to $66.2 \%$, depending on the extrusion conditions. It was suspected that phytic acid had more chance to form complexes with protein, starch or fibre when it was under high temperature and mechanical stress, thus reducing its solubility in the hydrochloric acid solution. To confirm this hypothesis, the extruded rice bran was treated with protease, cellulase or $\alpha$-amylase before phytic acid extraction. It appeared that hydrolysing the protein or starch in the extruded rice bran by protease or $\alpha$ amylase did release phytic acid from binding with these macromolecules, and increased extractability significantly $(p<0.05)$. However, extractability of phytic acid was not affected by cellulase treatment, suggesting that extrusion might not induce binding between phytic acid and cellulose or hemicellulose (Table 1).

Residence time, the duration that the rice bran stayed in the extruder during the process, ranging from 20 to 180 s, did not have any significant effect on the extractability of phytic acid $(p>0.05)$, as shown in Fig 2 . To obtain the highest processing efficiency, the shortest processing time (ie $20 \mathrm{~s}$ ), corresponding to a screw speed of $140 \mathrm{rpm}$, should be used for stabilising the rice bran. In addition, the rice bran processed at $130^{\circ} \mathrm{C}$ or above had a higher phytic acid extractability than that processed at lower temperatures (120 and

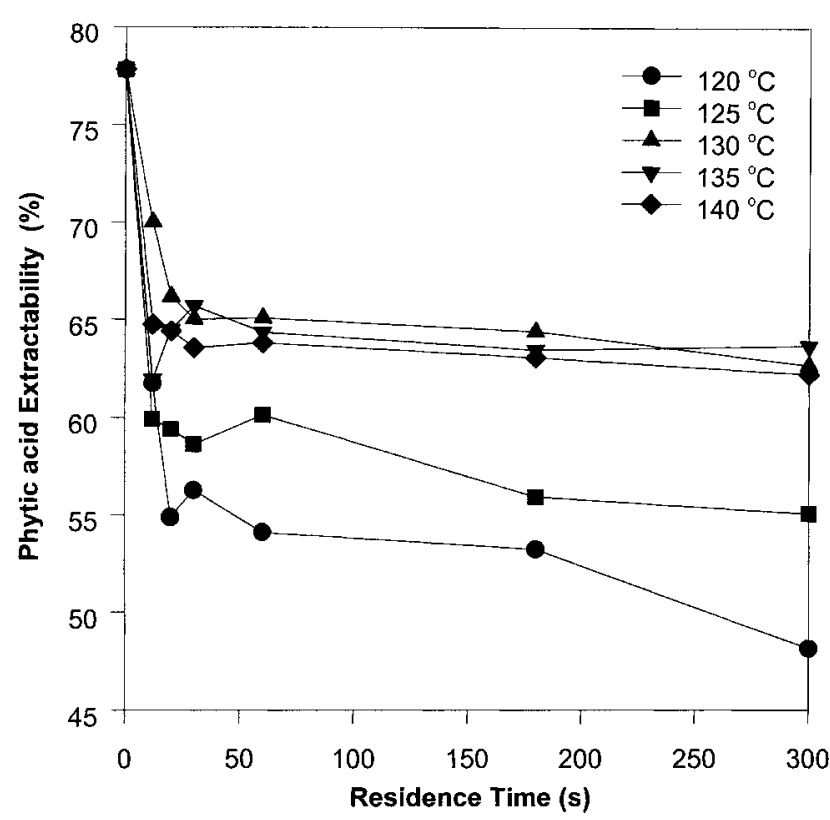

Figure 2. Extractability of phytic acid from rice bran extruded at various temperatures and residence times.

$125^{\circ} \mathrm{C}$ ). Considering both the rice bran storage stability and the phytic acid extractability, extrusion of rice bran was decided to be performed at $130^{\circ} \mathrm{C}$ for 20 s.

\section{Dephytinisation of rice bran}

The phytic acid content of the rice bran used in this study was analysed by HPLC and found to be $c a 9.3 \%$.

Table 1. Effect of enzyme treatment on the extractability of phytic acid from extruded rice bran by hydrochloric acid solution $\mathrm{n}^{\mathrm{a}, \mathrm{b}}$

\begin{tabular}{|c|c|c|c|c|c|}
\hline \multicolumn{2}{|c|}{ Extrusion conditions } & \multicolumn{4}{|c|}{ Extractability (\%) } \\
\hline $\begin{array}{l}\text { Temperature } \\
\left({ }^{\circ} \mathrm{C}\right)\end{array}$ & $\begin{array}{l}\text { Residence } \\
\text { time (s) }\end{array}$ & $\begin{array}{l}\text { Extraction without } \\
\text { enzyme treatment }\end{array}$ & $\begin{array}{l}\text { Extraction after } 1 \% \\
\text { cellulase treatment }\end{array}$ & $\begin{array}{l}\text { Extraction after } 1 \% \\
\text { protease treatment }\end{array}$ & $\begin{array}{l}\text { Extraction after } 1 \% \\
\text { amylase treatment }\end{array}$ \\
\hline 120 & 20 & 54.9b(ED) & $55.5 b$ & $84.0 a$ & $89.9 a$ \\
\hline 120 & 30 & 56.3b(BCDE) & $51.7 b$ & $75.4 a$ & 76.1a \\
\hline 120 & 60 & $54.1 b(\mathrm{DE})$ & $56.4 b$ & $64.0 a$ & 71.0a \\
\hline 120 & 180 & $53.3 b(E)$ & $55.2 b$ & $66.7 a$ & $65.8 a$ \\
\hline 125 & 20 & 59.4b(ABCDE) & 62.6b & $87.8 \mathrm{a}$ & 85.3a \\
\hline 125 & 30 & 58.6b(ABCDE) & $56.3 b$ & $83.7 \mathrm{a}$ & $78.5 a$ \\
\hline 125 & 60 & 60.1b(ABCDE) & $68.9 a$ & $74.7 a$ & 69.0a \\
\hline 125 & 180 & 55.9c(CDE) & 64.6b & 71.5ab & $62.4 \mathrm{bc}$ \\
\hline 130 & 20 & $66.2 b(A)$ & 67.0b & 87.0a & 72.1a \\
\hline 130 & 30 & $65.0 b(A)$ & $63.2 b$ & $81.3 a$ & $77.2 \mathrm{a}$ \\
\hline 130 & 60 & $65.1 b(A)$ & $64.2 \mathrm{~b}$ & $74.9 a$ & 66.0b \\
\hline 130 & 180 & $64.4 a(A B)$ & $62.7 a$ & $68.6 a$ & $64.6 a$ \\
\hline 135 & 20 & $64.5 b(A B)$ & $66.9 b$ & $81.5 a$ & $78.4 a$ \\
\hline 135 & 30 & $65.7 b(A)$ & $61.8 b$ & $77.8 \mathrm{a}$ & $75.5 a$ \\
\hline 135 & 60 & $64.4 \mathrm{ab}(\mathrm{AB})$ & $58.2 b$ & 68.3ab & $73.4 a$ \\
\hline 135 & 180 & $63.5 b(A B C)$ & $62.4 b$ & $66.1 \mathrm{ab}$ & $68.7 a$ \\
\hline 140 & 20 & $64.4 c(A B)$ & $64.4 \mathrm{c}$ & $95.7 a$ & $80.3 b$ \\
\hline 140 & 30 & $63.5 b(A B C)$ & $59.5 b$ & $79.6 a$ & $80.8 a$ \\
\hline 140 & 60 & $63.8 b(A B C)$ & $61.8 b$ & $81.6 a$ & $66.1 \mathrm{~b}$ \\
\hline 140 & 180 & $63.1 b(A B C D)$ & $64.2 b$ & $71.3 a$ & $65.8 b$ \\
\hline
\end{tabular}

a The extraction was carried out at $25^{\circ} \mathrm{C}$ for 30 min using hydrochloric acid solution at $\mathrm{pH} 2$ as solvent.

${ }^{b}$ The extractability of phytic acid from raw rice bran averaged $77.6 \pm 1.4 \%$.

Means within the same row followed by different lower-case letters are significantly different $(p<0.05)$.

Means within the same column followed by different upper-case letters are significantly different $(p<0.05)$. 


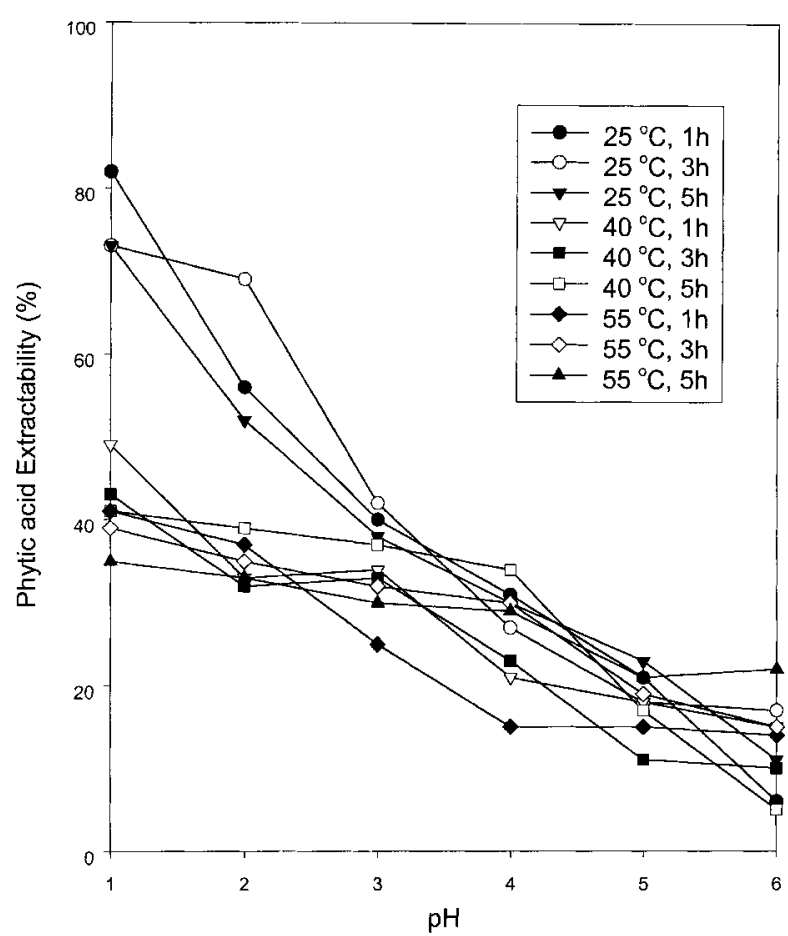

Figure 3. Effect of extraction temperature, time and solvent $\mathrm{pH}$ on the extractability of phytic acid from raw rice bran.

The effect of extraction temperature and time on the extractability of phytic acid from raw rice bran was investigated at 25,40 and $55^{\circ} \mathrm{C}$ for 1,3 and $5 \mathrm{~h}$ using $\mathrm{HCl}$ solutions of various $\mathrm{pH}$ values (1-6) as solvent, and the rice bran/solvent ratio was set at 1:5. As the $\mathrm{pH}$ of the extracting solvent increased, the phytic acid removal rate decreased (Fig 3). Moreover, when the $\mathrm{pH}$ of the extracting solvent used was above 4 , the mixture of solvent and solid became difficult to filter. It was suspected that degradation of macromolecules, such as starch, might occur at high $\mathrm{pH}$, and the small degraded particles in the mixture tended to foul the filter paper and obstruct the filtration process. Increasing the extraction temperature and time would further aggravate the filtration difficulty.

Raising the extraction temperature not only decreased the extraction rate of phytic acid but also darkened the colour of the rice bran and yielded an unpleasant odour, particularly at a $\mathrm{pH}$ above 4 . This suggests that when the rice bran was exposed to a weak acidic environment and high temperature, undesired chemical reactions occurred, damaging its quality. Fig 3 also shows that increasing the extraction time from 1 to $5 \mathrm{~h}$ did not exert any significant effect on the phytic acid extraction rate. Therefore it was concluded that the phytic acid removal process should be conducted at a relatively lower temperature and shorter time. Fig 4 shows the phytic acid removal rate and the purity of the extract when the extraction was carried out at $25^{\circ} \mathrm{C}$ for $0.5,1$ and $1.5 \mathrm{~h}$ at various $\mathrm{pH}$ values. The extraction conducted at $\mathrm{pH} 2$ for $30 \mathrm{~min}$ removed $c a$ $65 \%$ of phytic acid, and the purity of the phytic acid in the extract was the highest among the other $\mathrm{pH}$ values tested (ca 34\%).

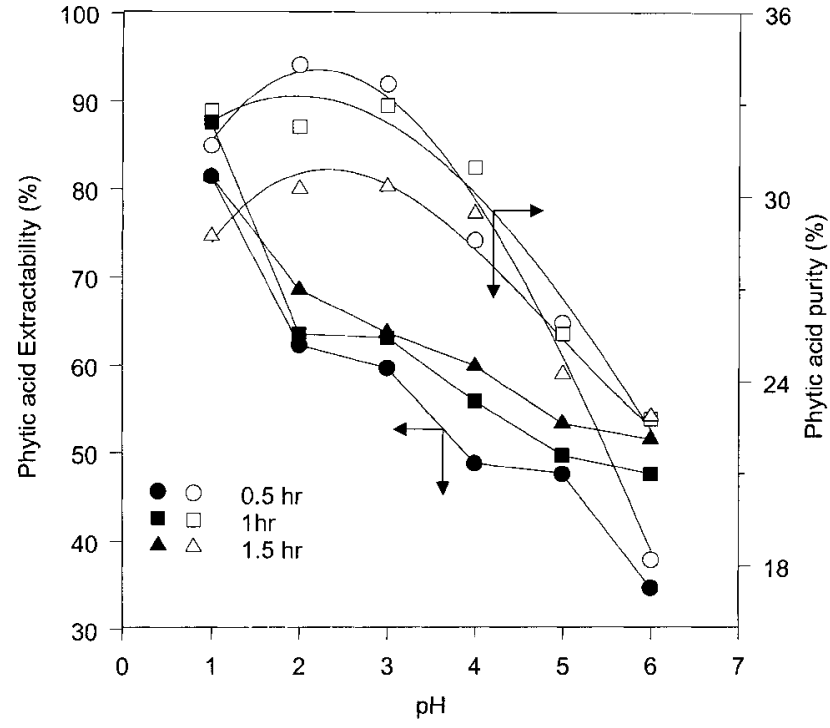

Figure 4. Effect of solvent $\mathrm{pH}$ and extraction time on the extractability of phytic acid and the purity of phytic acid in the extract. Extraction was conducted at $25^{\circ} \mathrm{C}$ and the solvent/rice bran ratio was 5 .

The phytic acid removal rate was also influenced by the solvent/rice bran ratio during extraction. Increasing the solvent/rice bran ratio, in general, increased the amount of phytic acid removed (Fig 5). However, the extractability reached a plateau and the purity of the phytic acid in the extract decreased dramatically when the solvent/rice bran ratio exceeded 15 . To reduce the difficulty in separating and purifying phytic acid from the extract, the phytic acid removal process should use an $\mathrm{HCl}$ solution of $\mathrm{pH} 2$ as solvent and should be carried out at $25^{\circ} \mathrm{C}$ for $30 \mathrm{~min}$ using a solvent/rice bran ratio of 15 . Under these conditions, nearly $94 \%$ of phytic acid in the rice bran could be removed, and the extract contained $30.5 \%$ of phytic acid, which can be

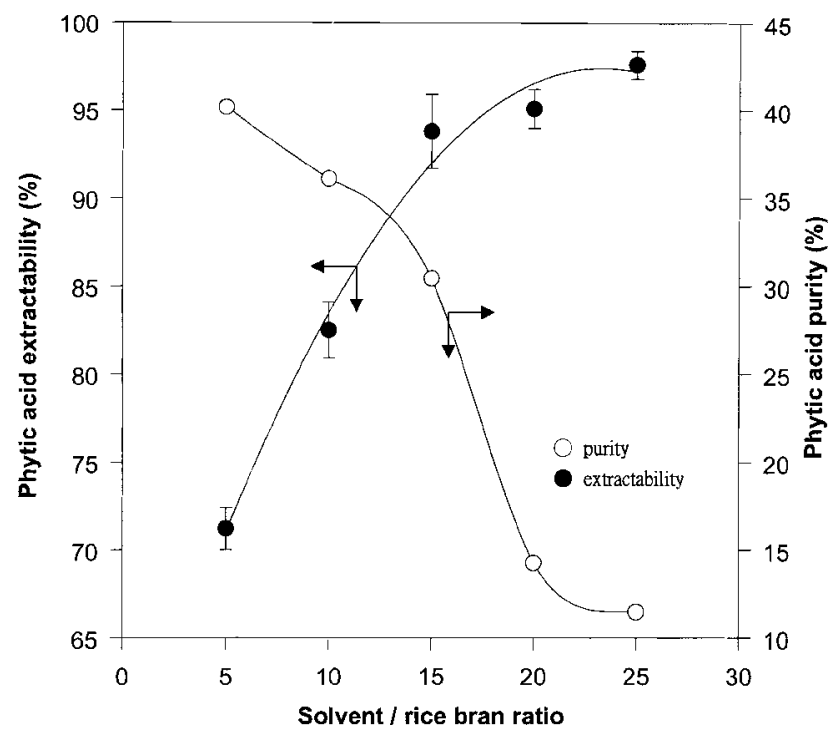

Figure 5. Effect of solvent/rice bran ratio on the extractability of phytic acid and the purity of phytic acid in the extract. Extraction was conducted at $25^{\circ} \mathrm{C}$ for $30 \mathrm{~min}$ 
Table 2. Changes in nutritional and some functional components of rice bran after extrusion, dephytinisation and drum drying

\begin{tabular}{lccc}
\hline Component & $\begin{array}{c}\text { Rice } \\
\text { bran }\end{array}$ & $\begin{array}{c}\text { Extruded rice bran } \\
\left(130^{\circ} \mathrm{C}, 20 \mathrm{~s}\right)\end{array}$ & $\begin{array}{c}\text { Dephytinised and } \\
\text { drum-dried rice bran }\end{array}$ \\
\hline Crude protein $(\% \mathrm{~N} \times 5.95)\left(\mathrm{g} \mathrm{kg}^{-1}\right)$ & $137.5 \mathrm{a}$ & $139.5 \mathrm{a}$ & $135.2 \mathrm{~b}$ \\
Crude fat $\left(\mathrm{g} \mathrm{kg}^{-1}\right)$ & $180.4 \mathrm{a}$ & $188.7 \mathrm{a}$ & $178.1 \mathrm{~b}$ \\
Crude fiber $\left(\mathrm{g} \mathrm{kg}^{-1}\right)$ & $46.0 \mathrm{a}$ & $49.6 \mathrm{a}$ & $42.8 \mathrm{a}$ \\
Ash $\left(\mathrm{g} \mathrm{kg}^{-1}\right)$ & $81.0 \mathrm{ab}$ & $80.8 \mathrm{a}$ & $78.1 \mathrm{~b}$ \\
Phytic acid $\left(\mathrm{g} \mathrm{kg}^{-1}\right)$ & $93.1 \mathrm{a}$ & $92.4 \mathrm{a}$ & $5.5 \mathrm{~b}$ \\
Niacin $\left(\mathrm{mg} \mathrm{kg}^{-1}\right)$ & $767.7 \mathrm{a}$ & $761.2 \mathrm{a}$ & $746.2 \mathrm{a}$ \\
Vitamin $\mathrm{B}_{2}\left(\mathrm{mg} \mathrm{kg}^{-1}\right)$ & $1.8 \mathrm{a}$ & $1.6 \mathrm{~b}$ & $1.5 \mathrm{c}$ \\
Vitamin $\mathrm{B}_{1}\left(\mathrm{mg} \mathrm{kg}^{-1}\right)$ & $26.7 \mathrm{a}$ & $25.2 \mathrm{~b}$ & $25.2 \mathrm{~b}$ \\
Oryzanol $\left(\mathrm{g} \mathrm{kg}^{-1}\right)$ & $5.2 \mathrm{a}$ & $5.0 \mathrm{a}$ & $2.7 \mathrm{~b}$ \\
IDF $\left(\mathrm{g} \mathrm{kg}^{-1}\right)$ & $245.0 \mathrm{~b}$ & $254.3 \mathrm{a}$ & $238.6 \mathrm{c}$ \\
SDF $\left(\mathrm{g} \mathrm{kg}^{-1}\right)$ & $55.3 \mathrm{a}$ & $50.3 \mathrm{~b}$ & $43.7 \mathrm{c}$ \\
Phosphorus $\left(\mathrm{g} \mathrm{kg}^{-1}\right)$ & $16.0 \mathrm{a}$ & $16.2 \mathrm{a}$ & $0.3 \mathrm{~b}$ \\
Potassium $\left(\mathrm{g} \mathrm{kg}^{-1}\right)$ & $6.9 \mathrm{a}$ & $6.5 \mathrm{a}$ & $0.4 \mathrm{~b}$ \\
Magnesium $\left(\mathrm{g} \mathrm{kg}^{-1}\right)$ & $6.9 \mathrm{a}$ & $6.5 \mathrm{a}$ & $0.2 \mathrm{~b}$ \\
Sodium $\left(\mathrm{mg} \mathrm{kg}^{-1}\right)$ & $155.6 \mathrm{~b}$ & $140.3 \mathrm{~b}$ & $254.3 \mathrm{a}$ \\
Calcium $\left(\mathrm{mg} \mathrm{kg}^{-1}\right)$ & $577.2 \mathrm{a}$ & $575.5 \mathrm{a}$ & $40.4 \mathrm{~b}$ \\
\hline
\end{tabular}

IDF, insoluble dietary fibre; SDF, soluble dietary fibre.

Means within the same row followed by different letters are significantly different $(p<0.05)$. further purified and used as a valuable ingredient for biochemical processes.

\section{Nutritional properties of rice bran product}

Table 2 shows the changes in the nutritional and functional components in the rice bran during processing. Most of these nutritional components in the rice bran were not damaged by the hightemperature/short-time extrusion process. However, vitamin $\mathrm{B}_{2}$ was sensitive to the stabilisation process. Approximately $8 \%$ of riboflavin decomposed owing to extrusion. Extrusion also caused an approximately $5 \%$ thiamin loss. Since nicotinic acid and oryzanol are relatively stable to heat, ${ }^{18,34}$ their concentrations were not significantly lower after extrusion $(p>0.05)$. The dephytinsation step removed nearly $95 \%$ of phytic acid, but caused less than $6 \%$ reduction of the major components in the extruded rice bran. The oryzanol, however, was relatively unstable. Approximately 50\% of oryzanol in the rice bran disappeared during dephytinisation and drum drying.

Rice bran contained $5.5 \%$ soluble dietary fibre (SDF) and $24.5 \%$ insoluble dietary fibre (IDF). The soluble portion of dietary fibre in rice bran, primarily composed of $\alpha-1,6$-glucan, has been proven capable of lowering serum cholestero ${ }^{13}$ and inhibiting the growth of cancer cells in rats. ${ }^{13}$ However, nearly $10 \%$ of SDF was lost during extrusion, and another $13 \%$ was lost after phytic acid extraction and drum drying. The IDF increased slightly ( $\mathrm{ca} 4 \%$ ) during extrusion, possibly owing to the conversion of SDF to IDF and of starch to resistant starch. Englyst et $a l^{35}$ also found that resistant starch was formed during the manufacture of cornflakes. Dephytinisation of rice bran by acid extraction, however, might have degraded part of the IDF, and the overall processes only caused minor IDF reduction ( $c a 2 \%)$.
Another concern of this investigation was the mineral content in the product. It was found that most of the major minerals, including phosphorus $(\mathrm{P})$, potassium $(\mathrm{K})$, magnesium $(\mathrm{Mg})$ and calcium $(\mathrm{Ca})$, originally present in the rice bran were lost during processing. The minerals were most likely chelated with phytic acid and removed from the rice bran during dephytinisation. The sodium content in the product, however, increased after processing. When the extruded rice bran was extracted for phytic acid with $\mathrm{HCl}$ solution, neutralisation of the extract with $\mathrm{NaOH}$ was necessary to precipitate phytate, and this step unavoidably added sodium ion to the product. Although part of the sodium would also be removed along with phytic acid, the neutralisation step still increased the sodium content in the product.

\section{CONCLUSION}

Rice bran was extruded at $130^{\circ} \mathrm{C}$ and $140 \mathrm{rpm}$ for $20 \mathrm{~s}$ with a twin-screw extruder to inactivate lipase and retard hydrolytic rancidity during storage. The above process condition induced a minimum amount of complex formation between phytic acid and protein as well as between phytic acid and starch, thus the phytic acid in the extruded rice bran could still be efficiently removed by solid/liquid extraction using hydrochloric acid solution at $\mathrm{pH} 2$ as solvent and conducted at $25^{\circ} \mathrm{C}$ for $30 \mathrm{~min}$. After the phytic acid had been precipitated and removed and the extract added back to the rice bran, the mixture could be dried using a drum dryer to manufacture a powdered product. Although insufficient in minerals, this rice bran product contains most of the other health-promoting components in the raw rice bran, but only a minor amount of phytic acid. Therefore it can be used as a new food ingredient. 


\section{ACKNOWLEDGEMENTS}

This research was supported by a grant (project NSC 88-2214-E002-013) from the National Science Council of Taiwan, ROC.

\section{REFERENCES}

1 Juliano BO and Hick PA, Rice functional properties and rice food product. Food Rev Int 12:71-103 (1996).

2 Prakash J and Ramanatham G, Effect of stabilisation treatment of rice bran on nutritional quality of protein concentrates. Int $\mathcal{F}$ Food Sci Nutr 46:177-184 (1995).

3 Prakash J, Rice bran proteins: properties and food uses. CRC Crit Rev Food Sci Nutr 36:537-552 (1996).

4 Kahlon TS, Chow FI, Chiu MM, Hudson CA and Sayre RN, Cholesterol-lowering by rice bran and rice bran oil unsaponifiable matter in hamsters. Cereal Chem 73:69-74 (1996).

5 Kahlon TS, Chow FI and Sarye RN, Cholesterol-lowering properties of rice bran. Cereal Food World 39:99-103 (1994).

6 Orthoefer FT, Rice bran oil: health lipid source. Food Technol 50:62-64 (1996).

7 Sharma RD and Rukmini R, Rice bran oil and hypocholesterolemia in rats. Lipids 21:715-723 (1986).

8 Kato A, Tanabe $\mathrm{K}$ and Yamaoka M, Esterified tocopherols and tocotrienols in rice bran oil, soybean oil, and sesame oil. fpn Oil Chem 30:515-516 (1981).

9 Sayre RN and Saunders RM, Rice bran and rice oil. Lipid Technol 2:72-74 (1990).

10 Okada T and Yamaguchi N, Antioxidant effect and pharmacology of oryzanol. Yukaku 32:305-310 (1983).

11 Rong NI, Ausman LM and Nicolosi RJ, Oryzanol decreases cholesterol absorption and aortic fatty streaks in hamsters. Lipids 32:303-309 (1997).

12 Aoe S, Oda T, Tatsumi K, Yamauch M and Ayano Y, Extraction of soluble dietary fibers from defatted rice bran. Cereal Chem 70:423-425 (1993).

13 Ito E, Takeo S, Kado H and Yamamoto H, Studies on antitumor polysaccharide RBS derived from rice bran: I. Preparation, physical-chemical properties and biological activities of RBS. Yakugaku Zasshii 105:188-193 (1985).

14 Fordyce EJ, Forbes RM, Robbins KR and Erdman JW, Phytate $\mathrm{X}$-calcium/zinc molar ratios: are they predictive of zinc bioavailability? F Food Sci 52:440-444 (1987).

15 Nolan K, Duffin PA and Mcweeny DJ, Effect of phytate on mineral bioavailability. In vitro studies on $\mathrm{Mg}^{2+}, \mathrm{Ca}^{2+}, \mathrm{Fe}^{3+}$, $\mathrm{Cu}^{2+}$ and $\mathrm{Zn}^{2+}$ (also $\mathrm{Cd}^{2+}$ ) solubilities in the presence of phytate. F Sci Food Agric 40:79-85 (1987).

16 Han YW, Removal of phytic acid from soybean and cottonseed meals. F Agric Food Chem 36:1181-1183 (1988).

17 Kimura G, Noda E, Zushi H, Takeuchi H and Tsukushiro US, Producing phytic acid. US Patent 3591665 (1971).

18 Vijayakumari K, Siddhuraju $\mathrm{P}$ and Janardhanan K, Effect of soaking, cooking and autoclaving on phytic acid and oligo- saccharide content of the tribal pulse, Mucuna monosperma DC. ex. Weight. Food Chem 55:173-177 (1996).

19 Chang R, Schwinmmer S and Burr HK, Phytate removal from whole dry beans by enzymatic hydrolysis and diffusion. $\mathcal{F}$ Food Sci 42:1098-1101 (1977).

20 Fredlund K, Asp NG, Larsson M, Marklinder I and Sandberg AS, Phytate reduction in whole grains of wheat, rye, barley and oats after hydrothermal treatment. F Cereal Sci 25:83-91 (1997).

21 Jayarajah CN, Tang HR, Robertson JA and Selvendran RR, Dephytinisation of wheat bran and the consequences for fibre matrix non-starch polysaccharides. Food Chem 58:5-12 (1997).

22 Sandberg AS and Svanberg U, Phytate hydrolysis by phytase in cereal; effect on in vitro estimation of iron availability. 7 Food Sci 56:1330-1333 (1991).

23 Knorr D, Watkins TR and Carlson BL, Enzymatic reduction of phytate in whole wheat bread. F Food Sci 46:1866-1869 (1981).

24 AOAC, Official Methods of Analysis, 14th edn. Association of Official Analytical Chemists, Washington, DC (1984).

25 Prosky L, Asp NG, Schweizer TF, DeVries JW and Furda I, Determination of insoluble, soluble and total dietary fiber in foods and food products: interlaboratory study. $\mathcal{F}$ Assoc Off Anal Chem 71:1017-1023 (1988).

26 Lehrfeld J, High-performance liquid chromatography analysis of phytic acid on a pH-stable, macroporous polymer column. Cereal Chem 66:510-515 (1989).

27 Shin TS and Godber JS, Changes of endogenous antioxidants and fatty acid composition in irradiated rice bran during storage. F Agric Food Chem 44:567-573 (1996).

28 Toma RB and Tabekhia MM, High performance liquid chromatographic analysis of $\mathrm{B}$-vitamins in rice and rice products. $\mathcal{F}$ Food Sci 44:263-266 (1979).

29 Feller DA, Rice bran stabilization and recovery of edible oiltechnical and financial feasibility. Food Rev Int 7:445-483 (1991).

30 Juliano BO, Rice: Chemistry and Technology. American Association of Cereal Chemists, St Paul, MN (1985).

31 Sayre RN, Saunder RM, Enochian RV, Schultz WG and Beagle EC, Review of rice bran stabilization system with emphasis on extrusion cooking. Cereal Foods World 27:318 (1982).

32 Randall JM, Sayre RN, Schultz WG, Fong RY, Mossman AP, Tibelhorn RE and Saunders RM, Rice bran stabilization by extrusion cooking for extraction of edible oil. $\mathcal{f}$ Food Sci 50:361-364 (1985).

33 Thompson LU, Antinutrients and blood glucose. Food Technol 42:123-132 (1988).

34 Cheldin VH, Woods AM and Williams RJ, Losses of B vitamins due to cooking of foods. $\mathcal{F}$ Nutr 26:477 (1943).

35 Englyst HN, Anderson V and Cammings JH, Starch and nonstarch polysaccharides in some cereal foods. I Sci Food Agric 34:1434-1440 (1986). 